\title{
Long-term outcome with sutureless valves: 12 years of Perceval experience
}

\author{
Delphine Szecel, Bart Meuris \\ Cardiac Surgery, University Hospitals Leuven, Leuven, Belgium \\ Correspondence to: Bart Meuris, MD, PhD. Cardiac Surgery, University Hospitals Leuven, Herestraat 49, Leuven 3000, Belgium. \\ Email: bart.meuris@uzleuven.be.
}

Submitted Feb 18, 2020. Accepted for publication Mar 18, 2020.

doi: $10.21037 /$ acs.2020.04.03

View this article at: http://dx.doi.org/10.21037/acs.2020.04.03

\section{Introduction}

The conventional treatment for aortic valve stenosis has always been surgical aortic valve replacement (AVR) using standard surgical valve prostheses. However, the use of transcatheter aortic valve implantation (TAVI) is expanding rapidly and currently TAVI paves its own way from intermediate- and high-risk patients to low-risk patients. This evolution has stimulated innovations within the field of surgical valves. Sutureless or rapid-deployment valves have been developed to make valve implantation faster, safer and less invasive. This design change continues to demonstrate that it has been an important and innovative strategy.

When looking at short-term outcomes, there are many studies and meta-analyses that have tried to compare standard valves, sutureless valves and TAVI among patients with a range of surgical risk levels. Recently, a network meta-analysis of 16,432 patients from seven randomized controlled trials and twenty-five propensity score-matched studies have compared all three options (1). While mortality and stroke outcomes were comparable for all three options, the sutureless AVR demonstrated less regurgitation than TAVI and less major bleeding and acute kidney injury than conventional AVR (1). Another meta-analysis reported less moderate to severe paravalvular leakage (PVL) and improved survival with sutureless AVR versus TAVI (2). Sutureless valves offer a faster implantation, with significantly reduced aortic cross-clamp and cardiopulmonary bypass times (2). The absence of a sewing ring may also result in improved hemodynamics (3). Unfortunately, prospective randomized data is still lacking.

\section{The Perceval sutureless valve}

The Perceval (LivaNova, London, UK) is a bioprosthetic heart valve made of bovine pericardium, built into a selfexpandable nitinol stent (3), which supports the valve and fixes it in place. It is suitable for implantation using standard surgical techniques or minimally invasive methods (3).

\section{Long-term follow-up with Perceval}

Clinical experience with the Perceval valve has reached more than 12 years since the first-in-man implants were performed in 2007 (4). The valve has now been implanted in more than 50,000 patients worldwide. Results from the (first-in-man, $\mathrm{n}=30$ ) pilot trial of Perceval showed-at the five year follow-up interval-one mild PVL, but no cases of dislodgement, structural valve deterioration, hemolysis or valve thrombosis (5). Hemodynamic performance results were good, with yearly single-digit mean gradients ranging from $7.6 \pm 3.6$ to $9.9 \pm 4.6 \mathrm{mmHg}$ (mean gradient) over five years (5). One of the centers from the pilot study (Leuven) used the Perceval valve on a daily basis and have, up to 2017 , treated a further 438 patients with Perceval. Their long-term follow-up results were made available at the 2019 American Association for Thoracic Surgery (AATS) meeting (6). These 468 patients (mean age 79 years) have now been followed for up to eleven years (mean followup of 3.5 years). Overall, two-year mortality was $14.8 \%$ (6), which compares favorably to outcomes from other studies in similar elderly patients. The mean gradient was $13 \pm 6 \mathrm{mmHg}$ at the latest available echo follow-up in all patients. During extended follow-up, four valves were 
explanted due to endocarditis and there was one case of structural valve degeneration (at 7 years) (6). Full results are due to be published soon (under review). The slightly elevated pacemaker implantation rate of $7.9 \%$ (6) has decreased to $4.7 \%$ in a consequent cohort of 190 patients from the same center after implementation of a new sizing strategy. These data were recently reported at the 2019 American Heart Association (AHA) meeting (7).

Combined results from three prospective, multicenter trials where Perceval valves were implanted in 731 patients (mean \pm SD age $79 \pm 5$ years) reported $25.9 \%$ using a minimally invasive approach (8). There were no cases of valve migration, structural valve degeneration, or valve thrombosis at the five-year follow-up (8). Mean gradient decreased from $42.9 \pm 16.4 \mathrm{mmHg}$ preoperatively to $10.3 \pm 4.4 \mathrm{mmHg}$ at discharge and again these remained relatively stable to five years (8). In a large single-center study, 617 patients (mean age $76 \pm 7$ years) were implanted with the Perceval valve (9). Only $1 \%$ of patients required reoperation. After a mean follow-up of 1.4 years (range, $0-4.3$ years), the survival rate was $91.3 \%$. Endocarditis occurred in two patients (at 6 and 10 months), one patient had valve degeneration, and one had pseudoaneurysm of the aortic root (9). Trivial or moderate PVL was present in thirty-three and three patients, respectively, at followup. In the ongoing CAVALIER trial (NCT01368666), 658 patients (mean age $78 \pm 6$ years) were implanted with the Perceval valve (10). At one-year follow-up, event rates were $8.1 \%$ for mortality, $3.0 \%$ for stroke, $1.9 \%$ for valverelated reoperation, $1.4 \%$ for endocarditis, and $0.6 \%$ for major PVL (10). There were no cases of valve thrombosis, migration, or structural valve deterioration, but the average follow-up was still limited (10). The full five-year followup results, including echo-core lab-reviewed data in all patients, are accepted for presentation at the next AATS meeting in 2020.

Despite use of the Perceval valve in more than 50,000 patients, there have been only rare case reports of late valve migration ( $\mathrm{n}=1 ; 5$ months after implantation) and early structural valve degeneration $(n=1 ; 2$ years after implantation).

\section{Conclusions}

Long-term follow-up data among patients implanted with the Perceval valve are promising, with low rates of PVL, the absence of dislodgement after proper valve seating, and low rates of structural valve deterioration or valve thrombosis. Several patients have now been implanted with this prosthesis for over twelve years, with good clinical and echocardiographic follow-up. Additional long-term followup data, including echo-core lab-reviewed hemodynamics are expected soon.

\section{Acknowledgments}

Medical writing support was provided by Jenny Lloyd (MedLink Healthcare Communications Limited).

This work was funded by LivaNova.

\section{Footnote}

Conflicts of Interest: BM is a consultant to LivaNova. DS has no conflicts of interest to declare.

Open Access Statement: This is an Open Access article distributed in accordance with the Creative Commons Attribution-NonCommercial-NoDerivs 4.0 International License (CC BY-NC-ND 4.0), which permits the noncommercial replication and distribution of the article with the strict proviso that no changes or edits are made and the original work is properly cited (including links to both the formal publication through the relevant DOI and the license). See: https://creativecommons.org/licenses/by-nc-nd/4.0/.

\section{References}

1. Lloyd D, Luc JGY, Indja BE, et al. Transcatheter, sutureless and conventional aortic-valve replacement: a network meta-analysis of 16,432 patients. J Thorac Dis 2019;11:188-99.

2. Powell R, Pelletier MP, Chu MWA, et al. The Perceval Sutureless Aortic Valve: Review of Outcomes, Complications, and Future Direction. Innovations (Phila) 2017;12:155-73.

3. Chauvette V, Mazine A, Bouchard D. Ten-year experience with the Perceval S sutureless prosthesis: lessons learned and future perspectives. J Vis Surg 2018;4:87.

4. Shrestha M, Folliguet T, Meuris B, et al. Sutureless Perceval S aortic valve replacement: a multicenter, prospective pilot trial. J Heart Valve Dis 2009;18:698-702.

5. Meuris B, Flameng WJ, Laborde F, et al. Five-year results of the pilot trial of a sutureless valve. J Thorac Cardiovasc Surg 2015;150:84-8.

6. Meuris B, Szecel D, Eurlings R, et al. Sutureless AVR Experience in a Single Center: 11 Years of Use in 468 
Patients. 2019. Accessed 14 November 2019. Available online: https://www.aats.org/aatsimis/AATSWeb/ Association/Meetings/Annual_Meeting/99th_Annual_ Meeting/AATS_99th_Annual_Meeting_Abstracts/2019-a832-AATS.ASPX

7. Meuris B, Michiel M, Verstraete L, et al. Oversizing in Sutureless Aortic Heart Valves Leads to Higher Gradients and Increased Pacemaker Rates. 2019. Accessed 26 November 2019. Circulation 2019;140:A12791.

8. Shrestha M, Fischlein T, Meuris B, et al. European

Cite this article as: Szecel D, Meuris B. Long-term outcome with sutureless valves: 12 years of Perceval experience. Ann Cardiothorac Surg 2020;9(4):322-324. doi: 10.21037/ acs.2020.04.03 multicentre experience with the sutureless Perceval valve: clinical and haemodynamic outcomes up to 5 years in over 700 patients. Eur J Cardiothorac Surg 2016;49:234-41.

9. Concistre G, Chiaramonti F, Bianchi G, et al. Aortic Valve Replacement With Perceval Bioprosthesis: SingleCenter Experience With 617 Implants. Ann Thorac Surg 2018;105:40-6.

10. Fischlein T, Meuris B, Hakim-Meibodi K, et al. The sutureless aortic valve at 1 year: A large multicenter cohort study. J Thorac Cardiovasc Surg 2016;151:1617-26.e4. 